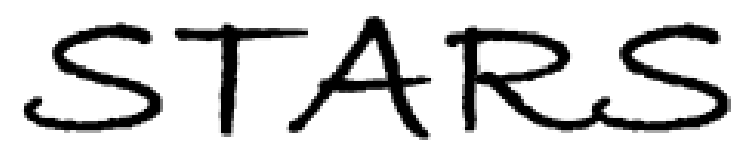

University of Central Florida

STARS

$1-1-2011$

\title{
Bandgap engineering of sol-gel synthesized amorphous Zn1-xMgxO films
}

\author{
M. Wei \\ University of Central Florida \\ R. C. Boutwell \\ University of Central Florida \\ J. W. Mares \\ University of Central Florida
}

A. Scheurer

University of Central Florida

W. V. Schoenfeld

University of Central Florida

Find similar works at: https://stars.library.ucf.edu/facultybib2010

University of Central Florida Libraries http://library.ucf.edu

This Article is brought to you for free and open access by the Faculty Bibliography at STARS. It has been accepted for inclusion in Faculty Bibliography 2010 s by an authorized administrator of STARS. For more information, please contactSTARS@ucf.edu.

\section{Recommended Citation}

Wei, M.; Boutwell, R. C.; Mares, J. W.; Scheurer, A.; and Schoenfeld, W. V., "Bandgap engineering of sol-gel synthesized amorphous Zn1-xMgxO films" (2011). Faculty Bibliography 2010s. 2086.

https://stars.library.ucf.edu/facultybib2010/2086

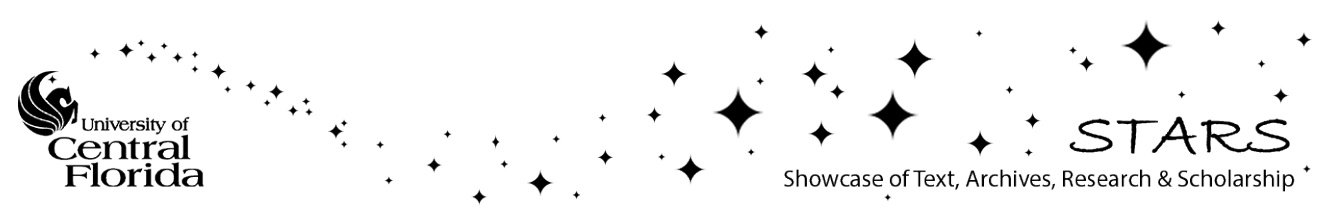




\section{Bandgap engineering of sol-gel synthesized amorphous $\mathrm{Zn}_{1-\mathrm{x}} \mathrm{Mg}_{\mathbf{x}} \mathrm{O}$ films}

Cite as: Appl. Phys. Lett. 98, 261913 (2011); https://doi.org/10.1063/1.3604782

Submitted: 03 March 2011. Accepted: 06 June 2011 . Published Online: 30 June 2011

M. Wei, R. C. Boutwell, J. W. Mares, A. Scheurer, and W. V. Schoenfeld

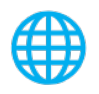

\section{ARTICLES YOU MAY BE INTERESTED IN}

$\mathrm{Mg}_{\chi} \mathrm{Zn}_{1-\mathrm{X}} \mathrm{O}$ as a II-VI widegap semiconductor alloy

Applied Physics Letters 72, 2466 (1998); https://doi.org/10.1063/1.121384

A comprehensive review of $\mathrm{ZnO}$ materials and devices

Journal of Applied Physics 98, 041301 (2005); https://doi.org/10.1063/1.1992666

Composition dependence of electrical and optical properties in sol-gel $\mathrm{Mg}_{\chi} \mathrm{Zn}_{1-\chi} O$ thin films Journal of Applied Physics 101, 023507 (2007); https://doi.org/10.1063/1.2426380

\section{Applied Physics Reviews} Now accepting original research 


\title{
Bandgap engineering of sol-gel synthesized amorphous $\mathrm{Zn}_{1-x} \mathrm{Mg}_{\mathrm{x}} \mathrm{O}$ films
}

\author{
M. Wei, R. C. Boutwell, J. W. Mares, A. Scheurer, and W. V. Schoenfeld ${ }^{a)}$ \\ CREOL, The College of Optics and Photonics, University of Central Florida, 4000 Central Florida Blvd., \\ Orlando, Florida 32816, USA
}

(Received 3 March 2011; accepted 6 June 2011; published online 30 June 2011)

\begin{abstract}
Amorphous $\mathrm{Zn}_{1-x} \mathrm{Mg}_{\mathrm{x}} \mathrm{O}\left(\alpha-\mathrm{Zn}_{1-\mathrm{x}} \mathrm{Mg}_{\mathrm{x}} \mathrm{O}\right)$ ternary alloy thin films across the full compositional range were synthesized by a low-cost sol-gel method on quartz substrates. The amorphous property of the $\alpha-\mathrm{Zn}_{1-\mathrm{x}} \mathrm{Mg}_{\mathrm{x}} \mathrm{O}$ films was verified by $\mathrm{x}$-ray diffraction, and atomic force microscopy revealed a smooth surface with sub-nanometer root-mean square roughness. The current phase segregation issue limiting application of crystalline $\mathrm{Zn}_{1-x} \mathrm{Mg}_{\mathrm{x}} \mathrm{O}$ with $38 \%<\mathrm{x}<75 \%$ was completely eliminated by growing amorphous films. Optical transmission measurements showed high transmissivity of more than $90 \%$ in the visible and near infrared regions, with optical bandgap tunability from $3.3 \mathrm{eV}$ to more than $6.5 \mathrm{eV}$ by varying the $\mathrm{Mg}$ content. (C) 2011 American Institute of Physics. [doi:10.1063/1.3604782]
\end{abstract}

Wide bandgap ternary and quaternary materials ${ }^{1,2}$ have been widely investigated recently for bandgap engineering through visible to deep ultraviolet (UV) regions. Among others, $\mathrm{Zn}_{1-\mathrm{x}} \mathrm{Mg}_{\mathrm{x}} \mathrm{O}$ is a promising candidate ${ }^{3,4}$ for applications such as transparent conducting oxides ${ }^{5}$ and optoelectronics devices in the UV spectral region. ${ }^{6}$ In principle, it has tunable bandgap from $3.3 \mathrm{eV}$ for wurtzite $\mathrm{ZnO}$ to $7.8 \mathrm{eV}$ for rock salt $\mathrm{MgO}$. Although the ionic radius of $\mathrm{Mg}^{2+}(0.57 \AA)$ is close to that of $\mathrm{Zn}(0.6 \AA)$, the crystal structure difference and large lattice mismatch between $\mathrm{ZnO}$ (wurtzite, $3.25 \AA$ ) and $\mathrm{MgO}$ (rock salt, $4.22 \AA$ ) causes phase segregation in $\mathrm{Zn}_{1-\mathrm{x}} \mathrm{Mg}_{\mathrm{x}} \mathrm{O}$ with $\mathrm{Mg}$ compositions between $37 \%<\mathrm{x}$ $<62 \%$. $^{4,6}$ As a result, development and subsequent application of $\mathrm{Zn}_{1-\mathrm{x}} \mathrm{Mg}_{\mathrm{x}} \mathrm{O}$ within the 4.27 and $5.4 \mathrm{eV}$ region has been hindered. This is a critical spectral window on the edge of the solar blind region (250-290 nm) where both detectors and emitters are necessary for many applications. Here, we report on a new route towards avoiding the current mixed phase issues for $\mathrm{Zn}_{1-\mathrm{x}} \mathrm{Mg}_{\mathrm{x}} \mathrm{O}$ within this spectral region, thus providing a new possible route towards controllable and reproducible energy gap tuning of optoelectronic devices based on this ternary.

Both phase segregation and lattice mismatch between substrate and film can be avoided by growing amorphous $\mathrm{Zn}_{1-\mathrm{x}} \mathrm{Mg}_{\mathrm{x}} \mathrm{O}\left(\alpha-\mathrm{Zn}_{1-\mathrm{x}} \mathrm{Mg}_{\mathrm{x}} \mathrm{O}\right)$ films. ${ }^{2,7,8}$ Amorphous films are usually very smooth, with few to no grain boundaries, and amenable to low temperature and large area deposition. Various deposition techniques have been employed to prepare $\mathrm{Zn}_{1-\mathrm{x}} \mathrm{Mg}_{\mathrm{x}} \mathrm{O}$ films, such as pulsed laser deposition (PLD), molecular beam epitaxy, metal-organic chemical vapor deposition, and RF magnetron sputtering. For preparing amorphous films, sol-gel ${ }^{9-11}$ has many advantages such as being cost-effective, being highly suitable for oxide materials, and providing excellent control of elemental composition and additives at molecular level. However, existing studies on sol-gel synthesized $\mathrm{Zn}_{1-\mathrm{x}} \mathrm{Mg}_{\mathrm{x}} \mathrm{O}^{9,11}$ are limited to low $\mathrm{Mg}$ concentration up to $\mathrm{x}=0.36$, corresponding to a bandgap of $3.93 \mathrm{eV}$. In this study, a sol-gel deposition method was

\footnotetext{
a) Author to whom correspondence should be addressed. Electronic mail: winston@creol.ucf.edu.
}

applied to fabricate $\alpha-\mathrm{Zn}_{1-\mathrm{x}} \mathrm{Mg}_{\mathrm{x}} \mathrm{O}$ thin films with full composition tuning $(\mathrm{x}=0-1)$, corresponding to bandgap energies from $3.3 \mathrm{eV}$ to more than $6.5 \mathrm{eV}$, providing a new route towards low-cost optoelectronic devices in the 200-300 nm spectral region.

The $\mathrm{Zn}_{1-\mathrm{x}} \mathrm{Mg}_{\mathrm{x}} \mathrm{O}$ thin films were synthesized on quartz substrates by the sol-gel method. Commercially available zinc acetate 2-hydrate $\left(\mathrm{Zn}\left(\mathrm{CH}_{3} \mathrm{COO}\right)_{2} \cdot 2 \mathrm{H}_{2} \mathrm{O}\right)$ and magnesium acetate 2-hydrate $\left(\mathrm{Mg}\left(\mathrm{CH}_{3} \mathrm{COO}\right)_{2} \cdot 2 \mathrm{H}_{2} \mathrm{O}\right)$ were dissolved in $20 \mathrm{ml}$ 2-methoxethanol. Diethanolamine $\left(\mathrm{HN}\left(\mathrm{CH}_{2} \mathrm{CH}_{2} \mathrm{OH}\right)_{2}\right)(\mathrm{DEA})$ was then added to the solution as the stabilizer. The total concentration of metal ions was maintained at $0.2 \mathrm{~mol} / \mathrm{L}$ and the molar ratio of the DEA to the total metal ions was $1: 1$. The percentage of $\mathrm{Mg}$ to total metal ions, $\mathrm{x}$, was adjusted from 0 to 1 to realize the full $\alpha-\mathrm{Zn}_{1-\mathrm{x}} \mathrm{Mg}_{\mathrm{x}} \mathrm{O}$ compositional range. For each metal ion ratio, the solution was stirred at $60{ }^{\circ} \mathrm{C}$ for 30 min and spin-coated on quartz substrates at $2000 \mathrm{rpm}$. The ascoated films were immediately preheated to $300{ }^{\circ} \mathrm{C}$ for $10 \mathrm{~min}$ to evaporate or burn off the solvent and other organic components in the film. To obtain a thickness of more than $300 \mathrm{~nm}$, this cycle was repeated ten times and then the film was postannealed in air atmosphere at $400{ }^{\circ} \mathrm{C}$ for $1 \mathrm{~h}$.

The $\mathrm{Zn}_{1-\mathrm{x}} \mathrm{Mg}_{\mathrm{x}} \mathrm{O}$ films were characterized by $\mathrm{x}$-ray diffraction (XRD) (Rigaku D/MAX x-ray diffractometer) using $\mathrm{Cu}-\mathrm{K} \alpha$ radiation $(\lambda=1.54056 \AA) .{ }^{12}$ The $\mathrm{Zn}_{1-\mathrm{x}} \mathrm{Mg}_{\mathrm{x}} \mathrm{O}$ films with $\mathrm{x}=0.2-1$ had no observable peaks at $2 \theta$ diffraction angles between $10^{\circ}$ and $90^{\circ}$, indicating an amorphous structure. In contrast, the pure $\mathrm{ZnO}$ film had peaks (FWHM $=0.65-0.7)$ at $2 \theta$ diffraction angles around $31.8^{\circ}, 34.41^{\circ}$, and $36.25^{\circ}$, attributed to the (100), (002), and (101) planes of wurtzite $\mathrm{ZnO}$, respectively. We subsequently found that the crystalline structure of $\mathrm{ZnO}$ could be suppressed and circumvented by lowering the post-annealing temperature to $300{ }^{\circ} \mathrm{C}$, resulting in a completely amorphous $\mathrm{ZnO}$ thin film. The amorphous nature and morphology of the $\alpha-\mathrm{Zn}_{1-\mathrm{x}} \mathrm{Mg}_{\mathrm{x}} \mathrm{O}$ films was further investigated using atomic force microscopy (AFM, Veeco Dimension 3100). The root-mean-square of the surface roughness of these films ranged from 0.3 to $1 \mathrm{~nm}$, showing no recognizable crystalline features for films annealed up to $400^{\circ} \mathrm{C}$ and indicating significantly smooth surfaces. For films annealed at higher temperature, crystalline 


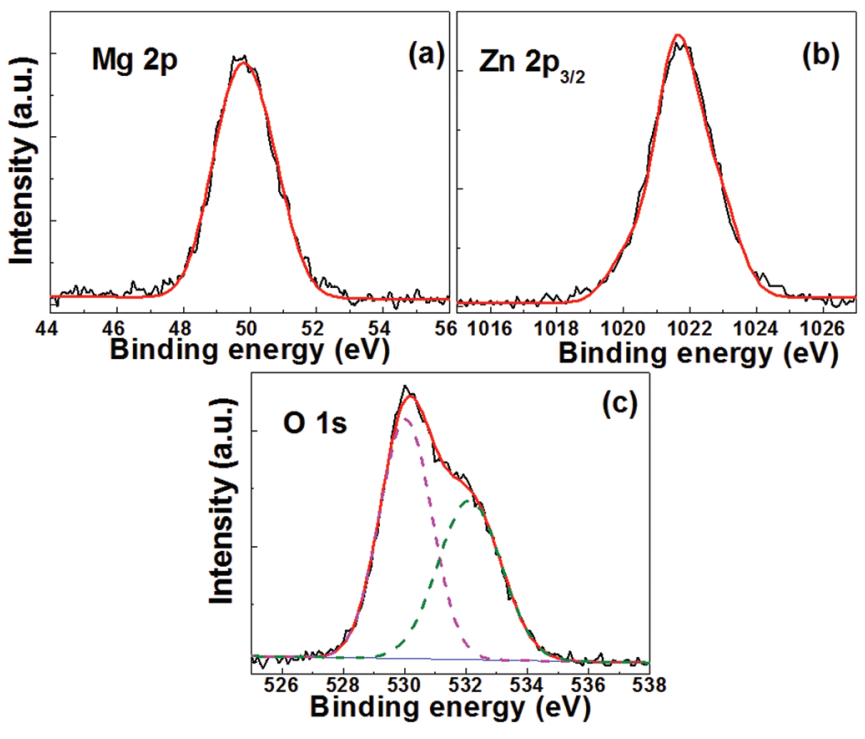

FIG. 1. (Color online) XPS spectra of $\mathrm{Zn}_{0.3} \mathrm{Mg}_{0.7} \mathrm{O}$ film: (a) $\mathrm{Mg} 2 \mathrm{p}$, (b) $\mathrm{Zn}$ $2 \mathrm{p} 3 / 2$, and (c) $\mathrm{O} 1 \mathrm{~s}$ with two resolved $\mathrm{O}$ bonding (dashed lines) components with peaks located at $530.04 \mathrm{eV}$ and $532.11 \mathrm{eV}$, respectively.

surface features were present, indicating that higher temperatures resulted in polycrystalline films. ${ }^{12}$

X-ray photoelectron spectroscopy (XPS, Physical Electronics 5400 ESCA) was carried out using an Al-K $\alpha$ X-ray source to analyze the composition. The position of the $\mathrm{C} 1 \mathrm{~s}$ peak was taken as a standard with a binding energy of $285.0 \mathrm{eV}$. Figure 1 shows the XPS spectra of an $\alpha-\mathrm{Zn}_{0.3}$ $\mathrm{Mg}_{0.7} \mathrm{O}$ film. Signatures of both $\mathrm{Zn}$ and $\mathrm{Mg}$ atoms are clearly observed in the XPS spectra of the film. The ratio of $\mathrm{Zn} / \mathrm{Mg}$ was determined to be 30.3:69.7 using AUGERSCAN3 software. This is in good agreement with the initial ratio (30:70) in the precursor solution, indicating that the ratio of $\mathrm{Zn} / \mathrm{Mg}$ in the solutions is maintained in the amorphous films after deposition and annealing at low temperature. Figure 1(c) shows the XPS spectra of O1s and its two Gaussian-resolved components centered at $530.04 \mathrm{eV}$ and $532.11 \mathrm{eV}$, respectively. The lower binding energy component centered at $530.04 \mathrm{eV}$ is attributed to $\mathrm{O}^{2-}$ ions in the $\mathrm{Zn}-\mathrm{O}$ and $\mathrm{Mg}-\mathrm{O}$ bonds, while the other component located at $532.11 \mathrm{eV}$ shows the presence of loosely bound oxygen chemisorbed on the surface, e.g., $-\mathrm{OH},-\mathrm{CO}_{3}$, or absorbed $\mathrm{O}_{2} \cdot{ }^{13,14}$ No peaks were detected around a binding energy of $398 \mathrm{eV}$ (N1s), indicating that $\mathrm{N}$ related chemicals are burnt out or evaporated and no longer present in the amorphous films.

The transmission spectra for $\mathrm{Zn}_{0.3} \mathrm{Mg}_{0.7} \mathrm{O}$ films annealed at different temperatures, shown in Fig. 2(a), were generated using a Cary 500 UV-VIS spectrophotometer. The absorption edge of the film becomes sharper when annealed at $400{ }^{\circ} \mathrm{C}$ as compared to the as-deposited film. This was also observed for $\alpha-\mathrm{Zn}_{1-\mathrm{x}} \mathrm{Mg}_{\mathrm{x}} \mathrm{O}$ films of other compositions and most likely attributed to the burning off of organic chemicals in the film. However, at annealing temperatures higher than $450{ }^{\circ} \mathrm{C}$, all samples exhibited obvious transmission tails, indicating that phase segregation begins to occur in the films at annealing temperatures above $400{ }^{\circ} \mathrm{C}$. The phase segregation becomes rather pronounced at temperatures higher than $500{ }^{\circ} \mathrm{C}$ and two absorption edges at around $360 \mathrm{~nm}$ and $210 \mathrm{~nm}$ were observed in all cases, representing Zn-rich and
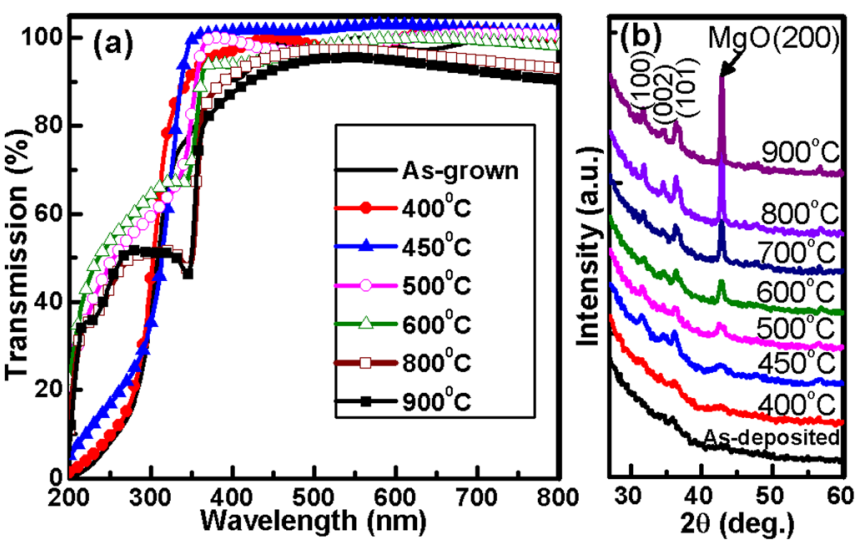

FIG. 2. (Color online) (a) Transmission spectra of as-grown $\mathrm{Zn}_{0.3} \mathrm{Mg}_{0.7} \mathrm{O}$ samples annealed for $1 \mathrm{~h}$ at various temperatures and (b) the corresponding XRD patterns. The wurtzite $\mathrm{ZnO}$ peaks (100), (002), and (101) and rock salt $\mathrm{MgO}$ peak (200) are indicated.

Mg-rich phases, respectively. ${ }^{15}$ When annealing at a temperature higher than $800^{\circ} \mathrm{C}$, the transmission curves changes little, implying that a stable crystalline $\mathrm{Zn}_{0.3} \mathrm{Mg}_{0.7} \mathrm{O}$ alloy with phase segregation has been obtained. We observed similar phase segregation signatures for $\mathrm{Zn}_{1-\mathrm{x}} \mathrm{Mg}_{\mathrm{x}} \mathrm{O}$ with $\mathrm{x}=0.5$ and 0.75 when annealing at temperature higher than $450{ }^{\circ} \mathrm{C}$. These observations indicate that the optimal post-annealing temperature for $\alpha-\mathrm{Zn}_{1-\mathrm{x}} \mathrm{Mg}_{\mathrm{x}} \mathrm{O}$ is $400{ }^{\circ} \mathrm{C}$ in order to avoid crystalline films with phase segregation. As expected, for $\mathrm{Mg}$ concentration lower than 38\% (Ref. 16) or higher than $75 \%$, the phase segregation does not happen, even when annealing at $800{ }^{\circ} \mathrm{C}$. It is noteworthy that the phase segregation range of sol-gel synthesized $\mathrm{Zn}_{1-\mathrm{x}} \mathrm{Mg}_{\mathrm{x}} \mathrm{O}$ with $38 \%<\mathrm{x}$ $<75 \%$ is different from that grown by PLD $(38 \%<\mathrm{x}<$ $62 \%)^{4}$

The presence of phase segregation was further confirmed by XRD, as shown in Fig. 2(b). No obvious XRD peaks were observed for annealing up to $400^{\circ} \mathrm{C}$. For annealing at temperatures $\geq 450{ }^{\circ} \mathrm{C}$, the film begins to exhibit multiple peaks associated with both wurtzite and rock salt $\mathrm{ZnMgO}$, similar to the work by Wang et al. ${ }^{16}$ This is consistent with the transmission data in Figure 2(a), where phase segregation signatures were observed for annealing temperatures of $450^{\circ} \mathrm{C}$ and higher.

Figure 3(a) illustrates the optical transmission spectra of $\alpha-\mathrm{Zn}_{1-\mathrm{x}} \mathrm{Mg}_{\mathrm{x}} \mathrm{O}(\mathrm{x}=0-1)$ in the wavelength range of 190 $800 \mathrm{~nm}$. It is observed that the films are highly transparent (greater than 90\%) in the visible and near infrared region of $400-800 \mathrm{~nm}$. This is attributed to low surface roughness of amorphous film since the scattering between the air and film interface increases when surface roughness increases. The absorption coefficient, $\alpha$, can be derived from the transmission T by Beer's law $T=I / I_{0}=e^{-\alpha d}$, where $I$ is the transmitted intensity, $I_{0}$ is the incident intensity, and $d$ is the thickness of the film, as measured by standard profilometry, varying from $170 \mathrm{~nm}$ to $650 \mathrm{~nm}$. We generated a plot of $(\alpha h v)^{2}$ versus photon energy, hv, as shown in the inset in Figure $3(\mathrm{a})$, and used this to estimate the bandgap ${ }^{17}$ by linearly extrapolating to the energy ( $h v)$ axis as shown in the inset. The determined bandgap, $\mathrm{E}_{\mathrm{g}}$, as function of $\mathrm{Mg}$ concentration, $x$, is shown in Figure 3(b). It can be seen that the bandgap value increases linearly for $\mathrm{Mg}$ content up to 

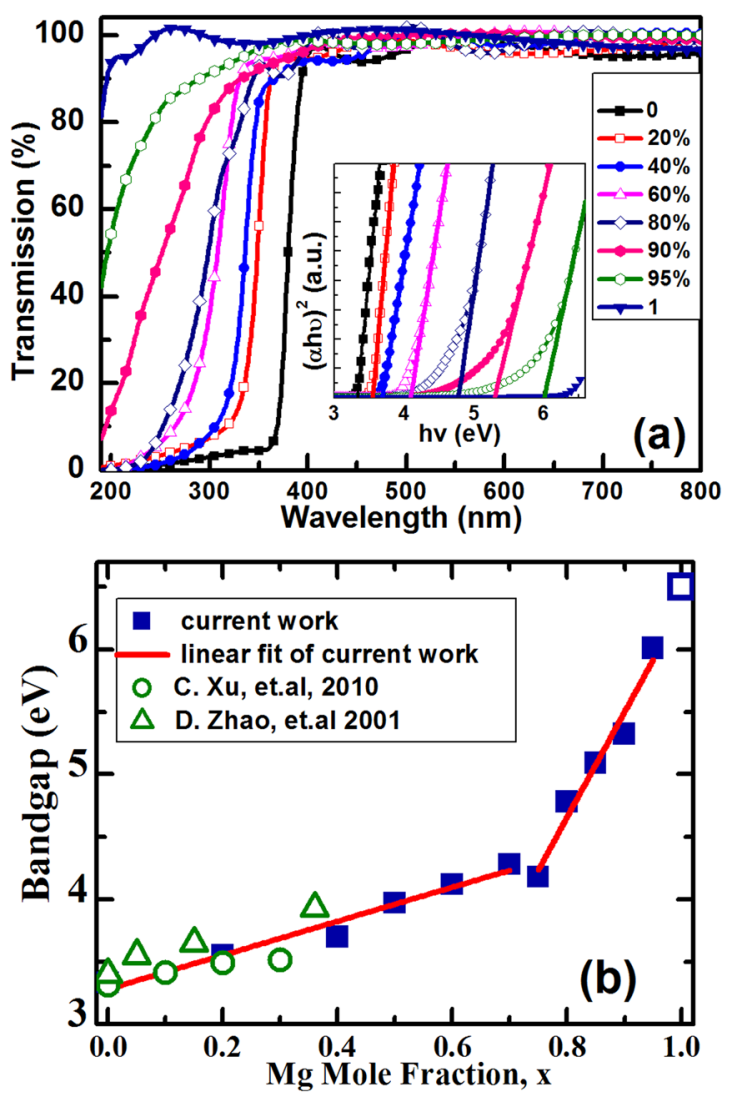

FIG. 3. (Color online) (a) Transmission spectra of $\alpha-Z_{n_{1-x}} \operatorname{Mg}_{x} \mathrm{O}$ films with different $\mathrm{Mg}$ concentration, $\mathrm{x}$, from 0 to 1 ; The inset shows the curve of $(\alpha \mathrm{h} v)^{2}$ versus photon energy hv. (b) The resultant bandgap of $\alpha-\mathrm{Zn}_{1-\mathrm{x}} \mathrm{Mg}_{\mathrm{x}} \mathrm{O}$ as a function of $\mathrm{Mg}$ concentration, including data from other works.

$\mathrm{x}=0.7$. For $\mathrm{Mg}$ content greater than 0.7 , a departure to another linear behavior is observed. These two linear fits are described by the following two equations:

$$
\begin{array}{ll}
E_{g}(x)=1.36 x+3.28 & \text { when } 0 \leq x \leq 0.7 \\
E_{g}(x)=8.4 x-2.064 & \text { when } 0.75 \leq x \leq 0.95
\end{array}
$$

It should be noted that the bandgap of high $\mathrm{Mg}$ content $(x>0.95)$ films could not be well determined since the absorption edge begins near the detection limit of the spectrometer at $\sim 190 \mathrm{~nm}$, limiting the number of data points available. Using the limited data, we observe that the bandgap for pure $\alpha-\mathrm{MgO}$ is larger than $6.5 \mathrm{eV}$ (open square in Figure 3(b)), indicating that the optical bandgap of $\alpha$ $\mathrm{Zn}_{1-\mathrm{x}} \mathrm{Mg}_{\mathrm{x}} \mathrm{O}$ is continuously tunable from $3.3 \mathrm{eV}$ to more than $6.5 \mathrm{eV}$. The values of bandgap determined in this work are in good agreement with those for crystalline films reported in other sol-gel publications, ${ }^{10,18}$ as shown in Figure 3(b). The slight difference in observed bandgap is mainly associated with a shift of absorption edge due to different post-annealing temperature of the films ${ }^{19}$ and resultant variations in crystallinity. The Urbach tail characteristic for amorphous $\mathrm{Zn}_{1-\mathrm{x}} \mathrm{Mg}_{\mathrm{x}} \mathrm{O}$ films at the absorbance edges with $\mathrm{Mg}$ concentrations up to $60 \%$ was also found. ${ }^{12}$ The width of the tail for $\mathrm{ZnO}$ was $0.089 \mathrm{eV}$, similar to that obtained by others for CVD $\mathrm{ZnO}(0.08-0.10 \mathrm{eV}){ }^{20}$
In summary, amorphous $\mathrm{Zn}_{1-\mathrm{x}} \mathrm{Mg}_{\mathrm{x}} \mathrm{O}$ films across the full compositional range were obtained using a sol-gel deposition method on quartz substrates, overcoming the known mixed phase region for the ternary and offering band gap tunability within the critical UV-C spectral region. Postannealing temperature was optimized to $400{ }^{\circ} \mathrm{C}$ to obtain a sharp absorption edge and to eliminate phase segregation issues intrinsic to crystalline $\mathrm{Zn}_{1-\mathrm{x}} \mathrm{Mg}_{\mathrm{x}} \mathrm{O}$ films. The ratio of $\mathrm{Zn} / \mathrm{Mg}$ in the precursor was found to remain in the amorphous films after annealing, simplifying band gap tuning, and $\alpha-\mathrm{Zn}_{1-\mathrm{x}} \mathrm{Mg}_{\mathrm{x}} \mathrm{O}$ films with high smoothness $(<1 \mathrm{~nm}$ RMS) and high transmissivity $(>90 \%)$ in the visible and near infrared regions were obtained. The bandgap of the films could be engineered continuously from $3.3 \mathrm{eV}$ to more than $6.5 \mathrm{eV}$ as the $\mathrm{Mg}$ concentration increases from $\mathrm{x}=0$ to $\mathrm{x}=1$, showing controllable tunability in the UV-C spectral region. Thus, sol-gel synthesized amorphous $\mathrm{Zn}_{1-\mathrm{x}} \mathrm{Mg}_{\mathrm{x}} \mathrm{O}$ films are a promising candidate for simple and low-cost fabrication of amorphous-based optoelectronic devices such as solar-blind detectors.

The authors would like to acknowledge financial support for this work by the U.S. Army Research Office under Contract No. W911NF-10-1-0159, monitored by Dr. Michael Gerhold.

${ }^{1}$ C. Yang, X. M. Li, Y. F. Gu, W. D. Yu, X. D. Gao, and Y. W. Zhang, Appl. Phys. Lett. 93, 112114 (2008).

${ }^{2}$ J. M. Khoshman, D. C. Ingram, and M. E. Kordesch, Appl. Phys. Lett. 92, 091902 (2008).

${ }^{3}$ U. Ozgur, Y. I. Alivov, C. Liu, A. Teke, M. A. Reshchikov, S. Dogan, V. Avrutin, S. J. Cho, and H. Morkoc, J. Appl. Phys. 98, 041301 (2005).

${ }^{4}$ I. Takeuchi, W. Yang, K. S. Chang, M. A. Aronova, T. Venkatesan, R. D. Vispute, and L. A. Bendersky, J. Appl. Phys. 94, 7336 (2003).

${ }^{5}$ K. Matsubara, H. Tampo, H. Shibata, A. Yamada, P. Fons, K. Iwata, and S. Niki, Appl. Phys. Lett. 85, 1374 (2004).

${ }^{6}$ W. Yang, S. S. Hullavarad, B. Nagaraj, I. Takeuchi, R. P. Sharma, T. Venkatesan, R. D. Vispute, and H. Shen, Appl. Phys. Lett. 82, 3424 (2003).

${ }^{7}$ J. M. Khoshman and M. E. Kordesch, Thin Solid Films 515, 7393 (2007).

${ }^{8}$ J. M. Khoshman, A. Khan, and M. E. Kordesch, J. Appl. Phys. 101, 103532 (2007).

${ }^{9}$ R. Ghosh and D. Basak, J. Appl. Phys. 101, 023507 (2007).

${ }^{10}$ D. X. Zhao, Y. C. Liu, D. Z. Shen, Y. M. Lu, J. Y. Zhang, and X. W. Fan, J. Appl. Phys. 90, 5561 (2001).

${ }^{11}$ C. S. S. Sandeep, R. Philip, R. Satheeshkumar, and V. Kumar, Appl. Phys. Lett. 89, 063102 (2006).

${ }^{12}$ See supplementary material at http://dx.doi.org/10.1063/1.3604782 for $\mathrm{x}$-ray diffraction patterns for films with different $\mathrm{Mg}$ concentrations in Figure S1, for AFM images in Figure S2, and for Urbach tail characteristic for amorphous films in Figure S3.

${ }^{13}$ H. Y. Xu, Y. C. Liu, C. S. Xu, Y. X. Liu, C. L. Shao, and R. Mu, Appl. Phys. Lett. 88, 242502 (2006).

${ }^{14}$ S. Ardizzone, C. L. Bianchi, M. Fadoni, and B. Vercelli, Appl. Surf. Sci. 119, 253 (1997).

${ }^{15}$ Z. G. Ju, C. X. Shan, C. L. Yang, J. Y. Zhang, B. Yao, D. X. Zhao, D. Z. Shen, and X. W. Fan, Appl. Phys. Lett. 94, 101902 (2009).

${ }^{16}$ M. Wang, E. J. Kim, S. Kim, J. S. Chung, I. K. Yoo, E. W. Shin, S. H. Hahn, and C. Park, Thin Solid Films 516, 1124 (2008).

${ }^{17}$ J. Tauc, R. Grigorov, and A. Vancu, Phys. Status Solidi 15, 627 (1966).

${ }^{18}$ R. Ding, C. X. Xu, B. X. Gu, Z. L. Shi, H. T. Wang, L. Ba, and Z. D. Xiao, J. Mater. Sci. Technol. 26, 601 (2010).

${ }^{19}$ D. X. Zhao, Y. C. Liu, D. Z. Shen, Y. M. Lu, J. Y. Zhang, and X. W. Fan, J. Sol-Gel Sci. Technol. 23, 231 (2002).

${ }^{20}$ Y. Natsume, H. Sakata, and T. Hirayama, Phys Status Solidi A 148, 485 (1995). 